\title{
O Islã no Brasil: malês e "árabes", dois momentos da presença muçulmana no contexto brasileiro
}

\author{
Islam in Brazil. Males and "Arabs": two moments of the Muslim \\ presence in the Brazilian context
}

\begin{abstract}
Resumo
Este artigo apresenta alguns aspectos históricos da presença do Islã no Brasil e analisa acontecimentos como a revolta dos escravos Malês na Bahia e os fluxos migratórios de sírios e libaneses para o Brasil. Trata, portanto, de questões sobre a religião e sua estruturação nesses dois contextos históricos. $O$ objetivo central é demonstrar que a presença do Islã em solo brasileiro desde o século XIX, proporcionada pelo tráfico de escravos trazidos da África, conhecidos como malês, nada tem a ver com as comunidades muçulmanas que aqui se estabeleceram a partir do século $\mathrm{XX}$, com as imigrações sírias e libanesas. Esses dois momentos históricos tratados aqui a partir de pesquisa bibliográfica, que procurou analisar condições de possibilidades de estabelecimento desta religião em campo brasileiro, tendo a fase das imigrações sírias e libanesas responsáveis pelas comunidades contemporâneas. Nos dois casos, constata-se que o Islã no Brasil foi uma religião de estrangeiros, étnica, e que só agora parece se abrir para uma realidade mista, com a entrada de convertidos sem ascendência árabe. Não obstante, observa-se que mesmo tendo feito parte de um período da história, esta religião ainda é vista com certo estranhamento, mas se apresenta como mais uma opção no contexto religioso do país.
\end{abstract}

Edmar Avelar Sena*

Palavras-Chave: Islã; comunidade; etinicidade.

\begin{abstract}
This article presents the historical aspect about Islam in Brazil and analyzes some events as the revolt of Males slaves in the state of Bahia and also the migration of Syrians and Lebanese to Brazil. The purpose is to show that the presence of Islam in Brazil in the 19th century, was provided by the traffic of slaves brought from Africa, Known as Males, and that such traffic had no connection with Muslim communities installed in Brazil since the 20th century in the period of Syrian and Lebanese immigrations. These two historical moments have been reported here through bibliographic research that sought to find conditions of possibility of the establishment of this religion in the Brazilian field; such phase of Syrian and Lebanese immigration resulted in the contemporary communities, specially those of the Southeast region. In both cases we could say that in Brazil, Islam has been a non ethnic-oriented religion, and only nowadays it seems to open towards a mixed reality, specially with the conversion of non-Arabs to Islam in Brazil. Nevertheless, we observe that even having been parto $\mathrm{f}$ Brazilian history, Islam is still seen in a suspicious way by Brazilians and appears as an additional option in the Brazilian religious context.
\end{abstract}

Keywords: Islam; community; ethnicity.

\footnotetext{
Artigo recebido em 12 mai. 2015 e aprovado em 30 de junho de2015

* Professor do Departamento de Ciência da Religião da Pontíficia Universidade Católica de Minas Gereais. País de Origem: Brasil. E mail: edmarsena.mg@gmail.com
} 


\section{Introdução}

O Islã apresenta-se, no contexto da realidade brasileira atual, apesar dos números pouco expressivos do Censo IBGE 2010, discordantes da percepção dos seus membros, como mais uma opção religiosa. Esta religião, no passado, se resumia a grupos étnicos, mas foi se transformando e, atualmente, começa a dar sinais de uma religião de caráter universalista, por se abrir mais à sociedade local e receber adeptos sem ascendência árabe.

Entretanto, o Islã ainda é visto como uma religião “de fora” e, assim, é facilmente alvo de estereótipos e preconceitos devido ao seu "estranhamento" na sociedade brasileira. O que se conhece do Islã, muitas vezes, se resume ao que é divulgado pela mídiaํ․ Mas a relação dessa religião com a sociedade brasileira não é nova. Desde o século XIX o Brasil convive com grupos de muçulmanos, primeiro foram os escravos africanos, mais tarde os imigrantes sírios e libaneses, dos quais uma pequena parcela era de muçulmanos sunitas.

Faz-se necessário, antes de tudo, salientar a pertinência, para este artigo, da constatação feita por Pinto (2010a, p. 23) de que existe uma diversidade nas formas de interpretar, praticar e vivenciar o Islã. Essa diversidade é afirmada por Pace (2005) que assinala a característica plural dessa religião. Para esses autores, o Islã vem se adaptando, ao longo de sua história, em contextos socioculturais bem diferentes de sua origem. O Islã penetrou, historicamente, em várias realidades culturais, e isso foi responsável pela pluralização de modos de ser muçulmano que relacionaram cultura e vida religiosa: “[...] culturas nacionais, experiências históricas e trajetórias políticas sempre produziram diferentes culturas do Islã ou percepções religiosas e práticas através de diferentes nações muçulmanas [...]"(BAYAT, 2003, p. 5).

\footnotetext{
${ }^{1}$ Sobre este aspecto Said (1990), em seu livro "Orientalismo: o oriente como invenção do ocidente", demonstra como foi gerada ao longo da história uma forma de ver o oriente a partir da ótica do orientalismo, que para ele é uma construção acadêmica e doutrinal do ocidente. Esta construção favoreceu os diversos olhares que se têm sobre o oriente e o Islã. Após uma longa argumentação a respeito da construção desse orientalismo na história, o autor assinala como este conceito pode ser descrito na atualidade: "O orientalismo pode, desse modo, ser visto como um modo de escrita, visão e estudo regularizado ou orietalizado, dominado por imperativos, perspectivas e preconceitos ideológicos, ostensivamente adequados ao Oriente" (SAID, 1990, p. 209).
} 
Os muçulmanos estabelecem suas relações sociais a partir da ideia de Ummah, a comunidade universal, conceito importante para a construção da identidade religiosa islâmica. A Ummah islâmica, segundo Santos (2010), é um ideal no qual os muçulmanos do mundo todo se identificam, tendo como exemplo a comunidade formada pelos seguidores do profeta. Pertencer ao Islã significa, de certa forma, transcender à cultura árabe, o que tem gerado possibilidades de outras identidades, como sugere o título de um artigo de Oliveira (2006), ao tratar do fenômeno religioso do islamismo no Brasil denominado: "O Islã no Brasil ou o Islã do Brasil”.

Por terem se organizado a partir de diferentes grupos étnicos, as comunidades muçulmanas produziram, cada uma à sua maneira, meios de manifestar seu ideal de identidade. Construíram suas agremiações e associações religiosas. Os sírios e libaneses se abriram para outros grupos, instaurando, a partir daí, certo hibridismo ${ }^{2}$, característico da nova formação dessas comunidades. A questão da etnicidade3, dentro de um contexto social brasileiro, gerou ao longo do tempo um tipo de hibridismo responsável pela configuração atual das comunidades muçulmanas.

\section{Muçulmanos no Brasil: Malês e Árabes em contextos distintos}

Escravos malês e os imigrantes sírios e libaneses marcaram a história do Islã no Brasil em duas fases distintas. Os Malês deixaram traços do Islã e da cultura árabe no contato que tiveram com outros grupos religiosos oriundos da

\footnotetext{
${ }^{2} \mathrm{~A}$ hibridização refere-se ao modo pelo qual os grupos culturais se separam de seus contextos de origem e se recombinam com outros modos culturais, configurando novas práticas. O hibridismo não é um fenômeno superficial que consiste na mesclagem, por mútua exposição, de modos culturais distintos ou antagônicos. Produz-se graças à mediação de novos sentidos num processo dinâmico e continuado de culturas (CANCLINI, 1997).

${ }^{3}$ De acordo com Guibernau e Rex (2010), no reader intitulado The Ethinicty: nationalism, multiculturalism and migration, "o termo etnicidade vem se tornando cada vez mais crucial nas ciências sociais desde a década de 1960, período marcado pela consolidação do processo de descolonização na África e Ásia, com criação de vários novos Estados-nação. Argumentos anticoloniais e antiracistas contribuiram com o novo vocabulário no qual o termo "etnia" foi usado por sociólogos e outros, como Spoonley sugestionou, a reconhecer 'Os sentimentos positivos de pertença a um grupo cultural'." (SPOONLEY, 1993, p.45).
} 
África e escravizados na Bahia, como o candomblé. Já os sírios e libaneses construíram as bases do que são hoje as Sociedades Beneficentes Muçulmanas.

Contudo, ainda há certo estranhamento que permeia a ideia de um Islã no Brasil. A história e a discreta relação destas comunidades com a sociedade mais ampla, e sua inserção social, não foram suficientes para desmistificar por completo todas as visões estigmatizantes sobre esta religião. A ideia de uma religião "de fora", "fundamentalista" e "violenta", ainda prevalece sobre as iniciativas dialogais e relacionais que estes grupos concretizam.

Assim, este tópico apresenta estas duas fases da história do Islã no Brasil e, embora sejam duas fases distintas e descontínuas, foram estas as bases das comunidades islâmicas atuais que se configuram, não mais como grupos étnicos, mas como comunidades abertas, sendo a religião mais uma opção na oferta religiosa do campo religioso brasileiro. Haja vista que um grupo étnico, compreendido como um povo ou nação, mantém seu significado básico no sentindo em que descreve um grupo possuidor de algum grau de coerência e solidariedade, composto por pessoas conscientes, ao menos em forma latente, de terem origens e interesses comuns. Pois, um grupo étnico não é mero agrupamento de pessoas ou de um setor da população, mas uma agregação consciente de pessoas unidas ou proximamente relacionadas por experiências compartilhadas. (CASHMORE, 2000).

\subsection{Revolta dos Malês}

Para falar do Islã no Brasil imperial, focaremos, primeiramente, a temporalidade da terceira década do século XIX, mais precisamente o ano de 1835, durante o império, data na qual estourou o levante que ficou conhecido como Revolta dos Malês. 
Em 1835, a economia brasileira era estruturada sob os domínios da sociedade escravista, responsável por forte desigualdade social. O sistema vivia um contexto de intensas lutas entre movimentos emancipatórios, republicanos e separacionistas. A Bahia foi palco de muitas destas lutas. O ideal iluminista já se fazia presente entre a burguesia brasileira. Mas outros grupos sociais levantavamse contra a estrutura econômica e política da ex-colônia.

Nesse contexto, vale destacar a importância do levante de escravos muçulmanos, ocorrido em 25 de janeiro de 1835, que, segundo o historiador João José dos Reis, pode ser considerado como um dos mais importantes movimentos de escravos ocorrido nas Américas, embora pouca importância se tenha dado a tal evento na literatura que enfoca o período. $\mathrm{O}$ objetivo principal desse levante era a libertação dos escravos de Salvador e do Recôncavo baiano.

De acordo com Reis (2003), no ano de 1835, a população de Salvador era de 65.500 pessoas, entre africanos, brasileiros e europeus, sendo que os africanos representavam 33\% da população à época. Além dessa porcentagem de africanos, chama a atenção a menção que Reis faz a Katia Mattoso (1966), que calculou que 90\% da população livre dessa cidade vivia "no limiar da pobreza". Diante de tal quadro socioeconômico, esse historiador destaca a concentração de renda na capital baiana, que indicava que cerca de $10 \%$ dos mais ricos controlavam $66,9 \%$ da riqueza, enquanto os $30 \%$ mais pobres obtinham apenas 1,1\%. É dentro desse contexto que se dá a rebelião muçulmana.

O autor aprofunda a discussão, levantando uma série de fontes do período, historiadores, documentos oficiais e depoimentos que remontam ao evento:

A Bahia destacou-se como uma das regiões mais agitadas do país. Entre 1820 e 1840 , a província foi palco de um conflito anticolonial, revoltas militares, motins portugueses, quebra-quebras e saques populares, rebeliões liberais e federalistas, com laivos republicanos, e levante de escravos (REIS, 2003, p. 45). 
Segundo Reis, a data escolhida para estourar a revolta não foi por acaso. No calendário católico, o dia 25 de janeiro na Bahia corresponde à festa de Nossa Senhora da Guia, e faz parte das festividades do Bonfim. Mas, segundo Reis, para os malês, essa data correspondia a uma das festas do fim do mês do Ramadã, no Calendário islâmico:

A rebelião foi planejada para acontecer num momento especialíssimo do calendário religioso muçulmano, na verdade o mais importante: o mês do Ramadã.[...] Para confirmar estas informações, fiz a conversão do dia 25 de janeiro de 1835 da era de Cristo para o calendário muçulmano, e resultou o esperado: 25 de Ramadã A.H. 1250 (REIS, 2003, p. 262).

O historiador aprofundou um pouco mais sua pesquisa sobre a data escolhida para a revolta e, ao que tudo indica, a data corresponderia mais precisamente à "noite do poder ou da Glória”, festa na qual se recorda a revelação do Alcorão ao Profeta Mohammad. Esta festa precede o final do mês do jejum, mês sagrado para os muçulmanos:

Aproximava-se o final do jejum, e é possível que os malês celebrassem uma das festas que precedem o final do mês sagrado, o Lailat al Qadr, cuja tradução para os idiomas ocidentais é ora "Noite da Glória", ora "Noite do Poder" ou "Noite do Destino".[...] O Qadr representa a revelação da escritura sagrada a Muhammad, celebrando portanto a aproximação entre Alá e os homens (REIS, 2003, p. 263).

Segundo Verger (1987), a hora prevista para estourar o levante era aquela em que os escravos saíam das casas para buscar água nas fontes públicas, bem de manhã, pois, neste momento, estaria reunido grande número de insurgentes. Além disso, deveriam promover incêndios em diversos pontos da cidade para desviar a atenção da polícia.

Embora arquitetada pelos escravos africanos, chamados de malês, a revolta contou com africanos de outras etnias. Os malês eram os escravos com uma 
reconhecida identificação étnica e religiosa, trazida direta e objetivamente da África Ocidental: eram muçulmanos.

Segundo Bastide, o nome malê provém da região da África de onde eram oriundos esses escravos: "É evidente que esse termo é uma corrupção de Mali, nome de um dos reinos muçulmanos do vale do Niger, habitados por malikê, no século XII de nossa era” (BASTIDE, 1971, p. 204). Possuíam assim uma carga de organização política e, inclusive, militar, advindas das guerras e batalhas que traziam ainda frescas na memória e que estavam sendo travadas no continente africano. Assim, a categoria malê foi usada genericamente para classificar todo escravo que fosse muçulmano.

Na Bahia de 1835, os africanos muçulmanos eram conhecidos como "malês". A origem do termo tem sido objeto de disputa. Braz do Amaral, por exemplo, sugeriu que derivasse de "má lei", que seria como os católicos consideravam o Islã, em oposição à "boa lei" da religião católica.[...] o historiador americano R. K. Kent associou male com Malām, a palavra haussá tomada do árabe mu'allim, que significa "clérigo" ou "mestre". Nina Rodrigues, primeiro estudioso competente dos malês, sugeriu que o termo deriva de Mali, o poderoso Estado muçulmano da Costa do Ouro. Contudo, a explicação que nos parece mais sensata e direta é apresentada por Pierre Verger, Vincent Monteil e Vivaldo da Costa Lima, que associam o termo male a ìmále, expressão iorubá para muçulmano. İmále, por sua vez, é apontado por Kathleen Stasik como sendo derivado de Mali. [...] Dessa forma, Nina, Etienne, Bastide e outros estudiosos que apontam a etnia malinké como origem de male teriam passado por cima de um vocábulo mais próximo. Mali estaria então na origem da origem, na ordem / Mali - ìmále - male, que seria a etimologia mais plausível. [...] No entanto, deve ficar claro que na Bahia "malé" não denominava o conjunto de uma etnia africana particular, mas o africano que tivesse adotado o Islã, embora, se quisermos ser bem stritos e etnicamente corretos, malês seriam apenas nagôs islamizados. Porém, nagôs, haussás, jejes, tapas - enfim, indivíduos pertencentes a diversas etnias - eram tidos, se muçulmanos, por malês (REIS, 2003, p. 177).

No entanto, os haussás eram identificados como muçulmanos, a ponto de haussá e malê se tornarem sinônimos, embora eles se designassem mussulmi e rejeitassem a associação dos termos. A etnia haussá foi trazida para as Américas na metade do século XIX. Eles correspondiam entre 15 e $20 \%$ da população 
escrava na Bahia, os outros eram na maioria adeptos da religião dos orixás. Poderíamos dizer que havia na cidade de Salvador certo pluralismo religioso entre os africanos de 1835. Reis (2003) afirma que o Islã se expandia em meio à população africana dessa cidade.

O que se pode perceber é que a religião colaborou, por seus princípios, para a instauração da rebelião, pois foi liderada pelos malês, que já traziam em sua bagagem cultural um elo entre política e religião.

Decerto, é inútil delimitar em casos como este a fronteira exata entre religião e rebelião. Esta última começa onde aquela enuncia a predileção por um grupo oprimido. O próprio fato de africanos escravos e libertos professarem o Islamismo configurava uma cisão, um afastamento radical da máquina ideológica escravista e, portanto, uma rebeldia (REIS, 2003, p. 247).

A própria situação dos malês já era expressão de rebeldia, pois professavam uma religião diferente, no momento histórico em que a constituição do país (1824), em nome da "Santíssima Trindade", trazia a religião católica romana como religião oficial. Apenas era permitido aos seguidores das demais religiões o culto doméstico. Em outros termos, as religiões deveriam contentar-se em celebrar um culto privado, doméstico, vedada qualquer forma exterior de templo. Assim, as religiões africanas eram compreendidas como feitiçaria, superstição, curandeirismo. Realidade que não mudou após a Independência, pois continuaram a ser tratadas na órbita policial e não constitucional. Por isso, os malês estavam à margem da lei (REIS, 2003).

A rebelião que objetivava a liberdade foi deflagrada e durou somente algumas horas: três, no máximo. As armas dos rebeldes eram mínimas e o levante foi reprimido rápido, por ter sido denunciado pouco antes de os rebeldes conseguirem implementar seus planos. Mesmo assim, os insurgentes resistiriam ao aparato militar. Verger relata como foi a denúncia: 
Na véspera, por volta de nove horas da noite, ou seja, apenas oito horas antes do momento previsto para ação, uma mulher nagô emancipada, Guilhermina Roza de Souza, que tinha sido escrava de Firmino Joaquim de Souza Velho, veio prevenir seu vizinho da rua do Bispo, o cidadão André Pinto da Silveira, do que se tramava para o dia seguinte. [...] André Pinto da Silveira preveniu imediatamente o presidente da província e o chefe de polícia, Francisco Gonsalves Martins. Todas as disposições de defesa foram em seguida tomadas e a tropa alertada (VERGER, 1987, p. 340).

Foram, segundo Reis (2003), algumas centenas de participantes, cerca de 70 mortos, e outras centenas foram julgadas e punidas com prisão, açoites, deportação ou mortes. Deve-se levar em conta também o fato de que, ao contrário das demais revoltas, que começaram com tentativas de fuga em massa para organização na periferia, no interior, esta foi a primeira rebelião escrava ocorrida dentro da cidade, bem no centro de Salvador. Embora de curta duração, foi intensa, e sua relevância está em ter sido organizada por africanos muçulmanos que, impulsionados pelo sentimento religioso, não aceitavam a condição de escravos.

Assim terminou a revolta. O pequeno grupo de insurrectos tinha entretanto conseguido, em algumas horas, intimidar a guarda do palácio e resistir ao batalho de infantaria. Obrigaram a polícia a fechar-se em sua caserna da Mouraria e somente encontram resistência e contra-ataque na caserna da cavalaria [sic] (VERGER, 1987, p. 341).

Os julgamentos foram exaustivos, as investigações buscaram todos os participantes, determinaram todas as linhas de ação. E os castigos foram equivalentes. Cada execução de pena possuía seu ritual e sua significação política de exemplo. As sentenças de morte foram as mais pesadas; sem dúvida, os enforcamentos eram encarados como uma forma fundamental de intimidação para possíveis rebeldes em potencial. Foram quatro enforcados, todos devidamente registrados, todos com a pompa necessária. As execuções dos açoites foram menos espetaculares, talvez, mas não menos públicas. 
Baseado em grande parte nos autos da inquirição oficial, além de uma montanha de outros documentos inéditos, Reis vislumbra também quem eram esses escravos e nisso, certamente, está a grande força de sua obra.

Aguiar descreve as características desses escravos muçulmanos:

Os escravos muçulmanos se distinguiam dos demais pela vida austera que levavam, pela moral rígida que seguiam e pela moderação e sobriedade dos gestos e rituais. [...] a marca registrada desses escravos era a barba 'à la Cavaignaic', que usavam como símbolo de diferenciação étnica e religiosa. Os homens usavam ainda uma espécie de túnica branca típica do Sudão maometano junto com um gorro de onde pendia uma longa faixa branca. As mulheres usavam turbante, saias rendadas e chinelinhas (AGUIAR, 1997, p. 22).

O cenário religioso baiano de 1835 era, de certa maneira, plural. Dentro dessa pluralidade de crenças, o Islã teve importante papel. Os escravos muçulmanos usavam trajes do Islamismo e, no corpo, traziam pequenos pedaços de papel com trechos do Alcorão (conforme figura I), o que posteriormente foi chamado de patuá.

Os muçulmanos eram minoria na Bahia, mas não uma minoria desprezível. Considerando o tamanho dos grupos étnicos entre os quais o Islã estava mais difundido (haussás, bornos, tapas e nagôs), calculo terem sido eles $15 \%$ e $20 \%$ dos africanos de Salvador de 1835 - mas estou falando de pessoas que tinham compromisso variado com a religião. De fato a maioria dos iorubás vítimas dos conflitos que acabei de narrar era adepta do culto dos orixás. Na melhor das hipóteses o Islã representava na Bahia um concorrente de peso, num ambiente em que convivia com o culto dos orixás nagôs, dos vunduns jejes, dos iskoki haussás, dos inquices angolanos - entre outras expressões da religiosidade tradicional. Somem-se os santos do catolicismo crioulo - também abraçado por africanos - e se terá uma ideia do pluralismo religioso no seio da população africana e afro-baiana daquela época (REIS, 2003, p. 178).

Esses escravos muçulmanos deixaram marcas de sua estada no Brasil. Os amuletos religiosos, que depois foram denominados patuás, são exemplos dessas marcas, além do turbante, a barba e o cabelo ainda hoje usado pelos adeptos do Candomblé. Essa religião africana herdou elementos e traços da presença do Islã na Bahia, no século XIX. Além disso, o ideal de liberdade e de não submissão, 
afora a Deus, foram marcas deixadas na história política e social do Brasil. Mas, convém lembrar que, nem sempre para muitos escravos a liberdade não era o ultimo degrau ou o maior desejo a ser alcançado. Alguns cativos, mesmo em condições de cativeiro, tinham outros projetos de vida que não inclúam a liberdade, pois mais de $70 \%$ das alforrias no Brasil foram condicionais, ou seja, ainda os mancípios estavam presos aos laços morais e paternais da Casa Grande. Além disto, pesquisas atuais com testamento e inventários post-mortem tem demonstrado que muitos escravos recusaram as chamadas alforrias incondicionais.

A intensidade do levante muçulmano no Brasil está no seu conteúdo e na estrutura de sua organização, e não na duração do evento, que se tornou o primeiro e único levante muçulmano na história da América Latina.

\section{Figura 1 - Amuleto contendo trechos do Alcorão}

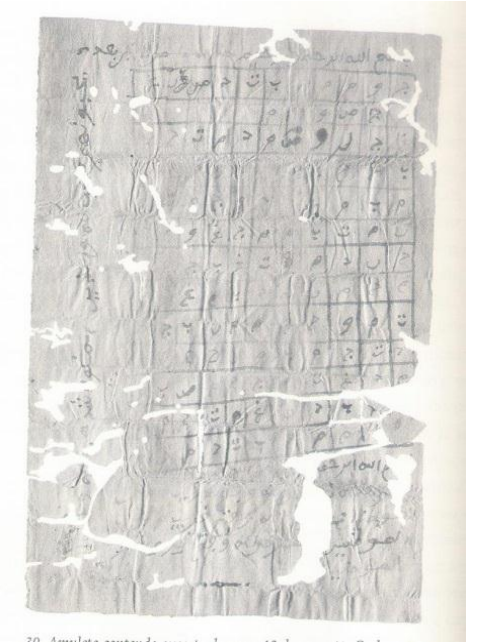

Fonte: REICHERT, 1970, doc. $\mathbf{2 8 . 4}$

\footnotetext{
${ }^{4}$ Rolf Reichert, Os documentos árabes do Arquivo Público do Estado da Bahia. Salvador, Centro de Estudos Afro-Orientais da Universidade Federal da Bahia, 1970, doc. N.28. Acervo da Apeba.
} 
O mais notável e difundido símbolo do Islamismo entre os africanos da Bahia foi o patuá, que consistia num pedaço de papel com alguns trechos do Alcorão que se trazia junto ao corpo, como forma de proteção: "no corpo do negro abatido foi encontrada uma espada e muitos papéis em língua árabe, contidos dentro de um saquinho" (VERGER, 1987, p. 341). O costume de usar esse amuleto, como forma de proteção, foi incorporado pelos demais africanos que não eram muçulmanos. Os muçulmanos difundiram esse amuleto e, juntamente com ele, a religião islâmica. Inquirindo os insurgentes sobre o que estava escrito naqueles papeis, pois a polícia pensava ser a trama de mais golpes por parte dos malês, eles respondiam, segundo Verger: "De suas respostas, ressaltava que aqueles papeis eram preces de male escritas pelos mestres da nação Ussá e alguns também na nação Tapa, que ensinavam os nagôs que os conheciam" (VERGER, 1987, p. 342). A polícia continuava sua investigação nos lugares que os escravos e emancipados habitam e nesses lugares descobriram mais papeis escritos com caligrafia árabe, que os mesmos julgavam ser planos dos rebeldes.

O conjunto de investigações nas habitações dos escravos e emancipados africanos levou à descoberta de numerosos papéis e brochuras descritas nos relatórios da polícia como sendo "escritos à maneira dos hebreus", "brochuras hebraicas", cobertos de caracteres "harabes", escritos "arabicamente", em "hiheroglificos" ou "em caracteres estrangeiros". De fato, tratava-se de inscrições extraídas do Alcorão que, colocadas dentro de pequenos saquinhos de couro, serviam de talismã aos africanos, insurrectos ou não. Tinham também encontrado tábuas que pensavam serem feitas para a impressão tipográfica ou litográfica, mas eram na realidade aquelas que serviam aos letrados para ensinar os versos do Alcorão a seus alunos.[...] Em sua ignorância, a polícia pensava que se tratava de papeis em caracteres desconhecidos, graças aos quais os insurrectos se comunicavam uns com os outros, o que lhes parecia provar pela presença, nos diversos lugares das investigações, de papéis e livros cobertos com a mesma misteriosa escrita. [...] A policia encontrava também durante as buscas uns rosários sem crucifixo, mas com um pequeno bastão na extremidade e argolas de metal branco (VERGER, 1987, p.343).

Nessa descrição de Verger aparecem outros elementos da religiosidade muçulmana, como as tábuas para a aprendizagem do Alcorão e o masbaha ou misbaha, também conhecido como tasbih ou tespih, que é um objeto similar a um 
rosário católico, de uso tradicional entre os fiéis da religião islâmica, dividido em três partes de trinta e três contas cada, sugerindo os 99 atributos de Aláh.

Reis lembra, ainda, o poder que a palavra escrita exerce para o crente muçulmano:

\begin{abstract}
A palavra escrita gozava de grande prestígio entre aqueles africanos mais familiarizados com a cultura oral, para os quais a escrita em si representava magia protetora da melhor espécie. Mesmo entre grupos islamizados como os fulanis, podiam ser encontrados indivíduos que apostavam no poder protetor da palavra escrita de extração não-islâmica. [...] Mas, num ambiente como a Bahia, a escrita ocidental não possuía tanta força mística entre os negros quanto os escritos islâmicos. Aqui, a popularidade do talismã islâmico remontava aos tempos coloniais, quando era conhecido como bolsa de mandinga.(...) Os amuletos malês eram em geral feitos de folha de papel contendo passagens do Qur'an e rezas fortes. Esses papéis eram escritos e cuidadosamente dobrados por gente entendida no assunto, até chegar a um tamanho de aproximadamente três a cinco centímetros - operação que também tinha seu mistério - e colocados dentro de bolsinhas de couro ou pano inteiramente costuradas. A função protetora aumentava com o número de amuletos carregados junto ao corpo (REIS, 2003, p. 181).
\end{abstract}

Talvez tenha sido o amuleto islâmico, tornado patuá, a herança mais forte da religiosidade muçulmana deixada pelos malês e incorporada à religiosidade brasileira. O patuá ganhou popularidade entre os filhos e pais de santo da religião dos Orixás e também do Catolicismo popular, agora não mais escrito com a caligrafia árabe, mas com orações dos santos católicos. Esse talismã retoma a história do Brasil e seu primeiro encontro histórico com Islã. É uma herança deixada pelos revoltosos malês. Este elemento se tornou pluri-religioso em grande parte da sociedade brasileira, que a utiliza como forma de expressar sua fé na proteção divina.

Os grupos muçulmanos de origem escrava entraram em declínio devido à repressão de sua religiosidade, o que fez com que muitos fossem deportados e outros se tornassem católicos. 


\subsection{Imigrações Sírias e Libanesas: nova presença muçulmana}

A relação do Islã com Brasil não desapareceu com os malês; outros imigrantes, não mais escravos, optaram por estabelecer residência em solo brasileiro. A partir do século XIX, vários fluxos imigratórios de sírios e libaneses tiveram como destino o Brasil. Muitos desses imigrantes vieram motivados por questões financeiras e, outros, atraídos pela publicidade para migração promovida pelo governo brasileiro. Eram em sua maioria homens solteiros e se ocuparam, primeiramente, de atividades ligadas ao comércio. O objetivo era claro, conforme o depoimento do senhor Omar, de 72 anos, membro da Sociedade Beneficente Muçulmana de Belo Horizonte: "Meu objetivo era vir para cá ganhar dinheiro, ficar rico e depois voltar para o Líbano. Isso, antes de vir, depois que cheguei não quis voltar mais.5” Assim, a pretensão inicial era uma emigração temporária, para amenizar as dificuldades financeiras enfrentadas por suas famílias. Entretanto, o que pretendia ser provisório acabou se tornando permanente: em vez de o imigrante retornar, em muitos casos, foi o restante da família que veio se juntar a ele no Brasil.

De acordo com Waniez e Brustlein (2001), entre as causas, que explicam a imigração síria e libanesa para o Brasil, pode se destacar o aprimoramento dos meios de transportes - o que facilitou o comércio internacional - , a "falta de infraestrutura urbana para absorver a população oriunda do campo, o contexto do Império Otomano, que colonizou a Síria e o Líbano e acirrou os conflitos étnicos, e, por fim, o desapego à terra natal” (WANIEZ; BRUSTLEIN, 2001, p. 158).

A parte muçulmana desse grupo de imigrantes sírios e libaneses, ao chegar ao Brasil, não teve ligações com as comunidades muçulmanas remanescentes dos malês. De acordo com Pinto, "as comunidades muçulmanas criadas pelos imigrantes árabes nunca se relacionaram com aquelas dos malês, sendo duas histórias descontínuas do Islã no Brasil” (PINTO, 2010a, p. 207). Segue-se daí a

\footnotetext{
${ }^{5}$ Nome fictício. Depoimento colhido por ocasião da pesquisa de campo realizado na Sociedade Beneficente Muçulmana de Minas Gerais - SBMMG em 2012.
} 
hipótese de que a origem histórica do Islã no Brasil, seja no período imperial escravista ou republicano, era formada basicamente por grupos étnicos, no primeiro caso, de africanos denominados de Malês e, no segundo caso, uma parte de sírios e libaneses, chamados de turcos ${ }^{6}$.

A minoria muçulmana, dentre o contingente de imigrantes sírios e libaneses, casou-se com mulheres cristãs e, talvez por esse motivo, os filhos nascidos aqui no Brasil não seguiram a religião do pai. "Ainda que o homem seja responsável, em última análise, pela família, a mulher domina o cotidiano familiar, sobretudo no que se refere à criação dos filhos até uma determina idade" (TRUZZI, 2008, p. 37). O senhor Omar também falou sobre essa situação: "A gente não tinha interesse em divulgar a religião não. Quem casou com mulheres cristãs, a educação religiosa dos filhos seguiu a mãe, né, é assim em quase todo lugar. E ser cristão também é ser bom” (Omar, 74 anos, imigrante).

A obra intitulada "Árabes no Rio de Janeiro", também de autoria de Paulo Gabriel Hilu Pinto da Rocha, demonstra bem o cenário e as condições de possibilidades que motivaram a vinda em massa de emigrantes sírios e libaneses para o Brasil. Segundo esse autor, uma série de fatores motivou o processo de emigração, dentre os quais destaca:

A interferência imperialista das potências europeias no Império Otomano e as tensões sociais e conflitos sectários que ela gerou podem ser consideradas como uma causa geral indireta do processo de imigração, uma vez que, em decorrência, criaram o contexto pelo qual a emigração vai desenvolver, mas não o fenômeno em si. O mesmo pode ser dito do processo de centralização política do Império Otomano e a consequente marginalização das elites urbanas árabes da sua burocracia administrativa (PINTO, 2010b, p. 27).

Entre os que emigraram, segundo Lesser (2001), cerca de $15 \%$ eram muçulmanos, outros eram cristãos ortodoxos, maronitas, melquitas, siríacos e uma

\footnotetext{
${ }^{6}$ Os passaportes que usavam até a Primeira Guerra mundial (1914-1918) era expedido pelo Império Otomano, por este motivo ficaram conhecidos como turcos.
}

Horizonte, Belo Horizonte, v. 13, n. 38, p. 829-861, abr./jun. 2015 - ISSN 2175-5841 
pequena parte era de judeus. Esse aumento do contingente de imigrantes sírios e libaneses se deu quando essa empreitada deixou de ser um projeto pessoal e passou a fazer parte de um projeto coletivo mais amplo. "Torna-se parte de uma mobilização coletiva que envolvia relações construídas a partir de laços de parentesco, localidade, posição social, imaginários culturais e identidades religiosas" (PINTO, 2010a, p. 27). Para Pinto (2010a), os momentos mais fortes da imigração se deram no primeiro quarto do século XX. Durante a Primeira Guerra, esse processo desacelerou, sendo retomado entre 1920 e 1926.

O Brasil foi, assim, se tornando, segundo a categorização feita por Montenegro, “terra na qual o Islã é minoria, mas pode se desenvolver livremente num ambiente de paz e de convivência com as demais religiões" (MONTENEGRO, 2002, p. 62). O Islã, no Brasil, constituído a partir da imigração, apresenta sua face plural através dos modos e representações que aqui se estruturaram.

Os imigrantes sírios e libaneses se estabeleceram em várias partes do país, mas sua presença foi maciça em São Paulo e região metropolitana, um contingente menor no Rio de Janeiro e vários grupos se espalharam pelo interior de Minas Gerais. Nessas localidades, desenvolveram sua atividade econômica, principalmente no comércio; em alguns lugares, ficaram conhecidos como mascates7. Sua principal ocupação nos países de origem era a agricultura, mas, no Brasil, abraçaram como profissão o comércio, ao contrário de outros imigrantes da época em que vinham para trabalhar nas lavouras. Tinham como objetivo serem donos do próprio negócio. Mascateavam nas zonas rurais, mas se estabeleceram nas cidades e nestas se fixaram em moradias populares, ou nos fundos das lojinhas que fundaram.

Devido à pluralidade de seu comércio, essa atividade, segundo Waniez e Brustlein (2001), estava no arquétipo do "turco" construído pela sociedade brasileira. As pessoas que falavam árabe no Brasil ficaram conhecidas como turcos.

\footnotetext{
${ }^{7}$ Nome dado ao vendedor ambulante associado popularmente à figura do "turco" imagem que os imigrantes tentaram dissociar devido aos estereótipos agregados a este epíteto.
} 
Os autores também lembram que uma pesquisa Vox Populi atribuiu aos "turcos" uma grande capacidade de adaptação dos usos e costumes brasileiros; os autores destacam, ainda, que, segundo o jornal Folha de S. Paulo, em 1995, os sírios e libaneses no Brasil eram uma população de 8 milhões de imigrantes: o dobro da população do Líbano na época.

\section{Figura 2 - "Mascate" fotografia de Marc Ferrez}

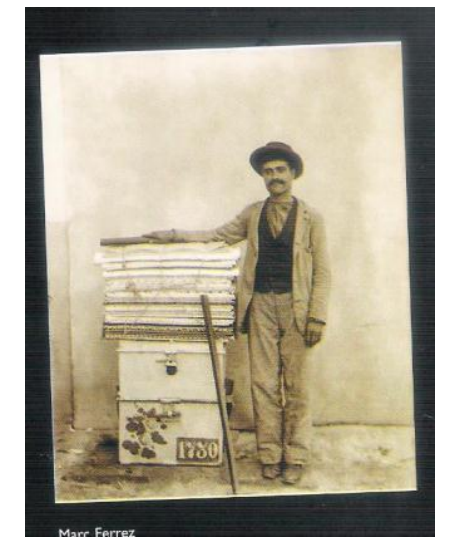

Fonte: FERREZ, 1899. ${ }^{8}$

Quanto ao número desses imigrantes adeptos do Islã, os autores acima apontam, de acordo com os números do IBGE, que o censo de "1991 divulgou o contingente de 22.449”. (WANIEZ; BRUSTLEIN, 2001, p. 16o), mas o número, segundo fontes muçulmanas (depoimentos dos imigrantes), apontava para um contingente muito maior. Esse mesmo dilema dos números apareceu quase uma década mais tarde e foi abordado por Oliveira.

Pensar em 27.239 ou 200.000, ou ainda 1.000.000, não significa dizer que todos que se designam muçulmanos são praticantes ou vão à mesquita. Na maioria das mesquitas visitadas, percebe-se uma grande discrepância entre o número de fiéis que é apresentado pela entidade e o número daqueles que frequentam as orações das sextas-feiras (OLIVEIRA, 2006, p. 85).

\footnotetext{
${ }^{8}$ Marc Ferrez. "Mascate” personagem anônimo,1899. Acervo do Instituto Moreira Salles.
} 
O censo do IBGE do ano de 2000 contabilizou 27.239 adeptos do Islã no Brasil, mas as comunidades muçulmanas sugerem que há mais de um milhão. No início do mês de julho de 2012, o mesmo instituto de estatística divulgou os dados do censo 2010 sobre religião, que apontou um tímido aumento do contingente de muçulmanos no Brasil. O número de adeptos do islamismo passou para 35.167.9 Contudo, o Centro de Divulgação do Islã para América Latina - CDIAL e revistas publicadas nas mesquitas, continuam afirmando que os muçulmanos no Brasil são mais de um milhão.

Portanto, nem antes nem agora os números ajudam muito sobre quantos são os muçulmanos no Brasil. Afora essa polêmica, o que mais interessa é a inserção dos adeptos do islamismo no cenário religioso brasileiro.

Pinto (2010a) informa que os anos 70 assistiram a mais um momento de intensa imigração de muçulmanos para o Brasil. Desta vez, as causas motivadoras da migração foram as tensões em territórios do Oriente Médio, a Guerra Civil Libanesa (1975-1990), as guerras árabe-israelenses e a ocupação israelense dos territórios palestinos e do sul do Líbano, agravados pela crise econômica local.

Cada grupo fundou sua entidade, que visava, acima de tudo, manter costumes, resgatar a identidade e vivenciar a religião. Fundar uma entidade assegurava acima de tudo a preservação de uma identidade que, inserida em outra realidade social, precisava ser resgatada e, uma vez resgatada, representava uma rede de solidariedade entre os imigrantes e seus descendentes.

Cada instituição representou a necessidade de organização dos diversos grupos étnicos que emigraram da Síria e do Líbano para o Brasil. Estes espaços tornaram-se centros de referências para atividades diversas, desde atividades recreativas a atividades de cunho religioso. Foram importantes para muitos imigrantes na sua inserção social na realidade brasileira, além de serem responsáveis pelas relações transnacionais dos diversos grupos. Tanto lá como

\footnotetext{
${ }^{9}$ Dados do censo 2010, divulgados em julho de 2012 (IBGE, 2012).
} 
aqui as organizações foram meios que favoreciam, por um lado, a manutenção de uma identidade e, por outro, auxiliavam no processo de inserção na nova realidade.

De acordo com Pinto (2010a) a ideia inicial de se reunir era, primeiramente, para preservar hábitos e costumes, assim como a história e a identidade, mas sem nenhuma pretensão de divulgar a religião. Basicamente, compostos por imigrantes, os grupos mantinham discreta relação com a comunidade local. Então, à medida que os grupos se encontravam, sentiram a necessidade de fundar uma associação. Aqui o elemento religioso aparece como motivação e, à medida que a religião tomava certa visibilidade frente à sociedade local, ficava clara a preocupação em resgatar a identidade religiosa. Posteriormente, construíram as mesquitas, primeiro em São Paulo, e depois em outras regiões do país.

Os diversos grupos de imigrantes sírios e libaneses que vieram para o Brasil foram agregados através de agremiações de cunho social e religioso. Nessas agremiações, o destaque estava nos momentos da vida comunitária. Os grupos se reuniam por ocasião das festas religiosas, que resgatavam as identidades étnicoreligiosas. Esses momentos fortaleciam também os aspetos da vida social dos imigrantes e seus familiares. Segundo Pinto (2010b), o principal signo expresso pelo ritual religioso, criado pelos imigrantes no Rio de Janeiro, era a língua árabe, mas, neste caso, não só pelos muçulmanos.

Todavia, afora os interesses econômicos no Brasil, esses imigrantes sírios e libaneses organizaram associações que tinham o objetivo de manter traços da cultura e da religião; assim, foram criando mesquitas, igrejas e clubes, espaços de socialização e de encontros. Sendo os muçulmanos a parte menor desse grupo de imigrantes, o espaço social deste foi discretamente construído. O objetivo dessas sociedades era manter a comunidade coesa com um local para a celebração das festividades religiosas e sociais. 
Os sírios eram, em sua maioria, praticantes do rito bizantino e fundaram no Brasil as igrejas melquitas. Já os libaneses, em grande parte, pertenciam ao rito maronita da igreja católica de Antioquia, mas havia também católicos armênios, siríacos e um pequeno número de judeus. Os ortodoxos fundaram a sua primeira agremiação religiosa em 1900: a Sociedade ortodoxa São Nicolau, no Rio de Janeiro. Como não dependiam do parecer da Igreja Católica Romana, logo se estruturaram:

Os ortodoxos foram os primeiros a construir instituições de cunho religioso, uma vez que não podiam contar com o quadro religioso ou institucional da Igreja Católica Romana. [...] Essa sociedade tinha como objetivo, além da mútua ajuda entre os ortodoxos do Rio de Janeiro, a organização de cultos e celebrações religiosas (PINTO, 2010b, p. 111).

No Rio de Janeiro, o primeiro espaço religioso fundado por imigrantes muçulmanos foi a comunidade Alauíta, grupo religioso xiita, em 1931, nela convergia o centro da vida religiosa, orações, festas e celebrações.

Até a aquisição da sede da Sociedade Alauíta, na Tijuca, as celebrações religiosas eram feitas na casa do shaykh (líder religioso) Hassan Ahmad Safatli, no Estácio, onde havia grande quantidade de famílias árabes alauítas e não alauítas (PINTO, 2010b, p. 127).

A organização social dos imigrantes sírios e libaneses, em torno das atividades religiosas, foi de certa forma uma saída encontrada por eles para manter tradições e preservar aspectos sociais e culturais do grupo. Assim, criaram as Sociedades Beneficentes Muçulmanas no Rio de Janeiro, São Paulo e em Minas Gerais, comunidades que hoje abrigam brasileiros sem ascendência árabe que aderiram ao Islã como religião.

\section{As comunidades muçulmanas na atualidade}

A Europa, cada vez mais, convive com um número crescente de adeptos do Islamismo, sejam eles imigrantes ou recém-convertidos. Demant (2004) nos dá 
mais informações sobre o Islã na Europa. Para esse autor, a religião adquiriu nova configuração no continente depois da Segunda Guerra Mundial:

Os muçulmanos da Europa se dividem em dois grupos completamente diferentes. Nos Bálcãs, na Europa ocidental e na Rússia se encontram descendentes de populações túrcicas e de grupos de nativos convertidos ao Islã, deixados sob autoridades não muçulmanas após a retirada otomana: bósnios servocratas e pomaks búlgaros (ambos convertidos do bogolismo, uma seita cristã medieval), tártaros (incluindo os da Criméia), chechenos do Cáucaso setentrional, bashquires e outros. Outro grupo são os imigrantes muçulmanos mais recentes na Europa, cuja maioria só chegou após os anos 60 e vive principalmente na Europa ocidental. Eles são estimados entre dez e quinze milhões, sendo que a maioria se encontra nas respectivas ex-potências coloniais ou senhores de esferas de influencia (DEMANT, 2004, p. 170).

Já o trabalho de Wohlrab-Sahr (2002), sobre os convertidos ao Islã nos Estados Unidos e na Alemanha, também ajuda a compreender a escolha por parte dos crentes por esta religião num contexto ocidental. Segundo a autora:

E deve haver um contexto social que torne a escolha religiosa possível, no sentido de permitir pensar sobre a conversão a uma religião, o que parece estranho a muitas pessoas nas sociedades ocidentais. Por esta razão, os muçulmanos convertidos submetem-se positivamente a uma situação pluralística que lhes permite desviar das orientações e comportamentos religiosos da maioria (WOHLRAB-SAHR, 2002. p. 4).

Ao analisar o contexto muçulmano europeu, Demant descreve as etapas de imigração do Islã para Europa:

Os muçulmanos chegaram à Europa essencialmente em três ondas. A primeira foi de nativos colaboradores com as potências coloniais, que terminam em represálias após a independência e que foram estabelecendo na metrópole, como os harkis na França. A segunda onda, muito maior, foi a dos trabalhadores-hóspedes (guest workers). Durante o período de expansão econômica européia durante os anos 60 e 70, que correspondeu à crescente miséria no Oriente Médio e na África do Norte, eles chegaram aos milhões para preencher as vagas menos desejáveis nas indústrias e serviços dos países capitalistas avançados. [...] Uma terceira categoria de imigrantes muçulmanos se juntou então às anteriores; refugiados políticos perseguidos nas inúmeras ditaduras do mundo 
muçulmano: Irã, Somália, Etiópia, curdos do Iraque, palestinos. Países como a França, Holanda e Suécia já tinham uma tradição secular de acolher vítimas de intolerância em outras partes. [...] Os números da terceira onda são muito menores do que da segunda, sendo cada caso julgado individualmente. Mesmo assim chegaram dezenas de milhares, e também acabaram provocando por sua vez reações nativas xenófobas (DEMANT, 2004, p. 172).

Segundo Walker, o Islã foi revelado em contexto árabe, o que não significa que seja uma religião árabe: "O islão não é uma religião especificamente árabe, mas a sua formulação e a sua expressão na Arábia infundiram aspectos a esta fé que só os Árabes lhe poderiam ter dado" (WALKER, 2005, p. 15). Assim sendo, pode-se afirmar que o Islã tem fortes ligações com a cultura árabe, mas não pertence só a este espaço. A experiência da Europa vem demonstrando que esta religião, em contextos diferentes, se relaciona com o Ocidente, tomando características do cenário onde se encontra. Assim, o Islã pode ser visto como uma religião étnica ou como mais uma opção religiosa para pessoas sem ascendência muçulmana.

Talvez tais experiências possam ajudar a entender o crescimento do número de convertidos ao Islã no Brasil contemporâneo e a configuração das comunidades muçulmanas presentes nas cidades brasileiras.

O número de muçulmanos nas Américas é muito pequeno, como foi dito. Em alguns países, quase invisível. Em outros, os grupos de imigrantes nem conseguiram se estruturar, ficando perdidos seus elos com a religião. Por serem muito discretos, principalmente na América Latina, há poucos estudos sobre estes grupos e comunidades e as estatísticas ficam quase sempre a encargo dos próprios crentes, o que dificulta chegar a um consenso de quantos são.

De qualquer forma, os EUA têm o maior número de muçulmanos nas Américas, sendo eles, principalmente, de imigrantes e negros convertidos ${ }^{10}$.

\footnotetext{
${ }^{10}$ De acordo com Demat (2004), os muçulmanos nos EUA chegam hoje a seis milhões de pessoas. Ligados à luta pelos direitos humanos e contra o racismo, os negros muçulmanos estadunidenses constituem o que o autor acima chamou de Nation of Is/am. Um personagem conhecido desse grupo foi Malcolm X, assassinado em 1965, pregava uma independência negra nos EUA.
} 
Entretanto, mesmo tendo um contingente considerável de muçulmanos, os EUA encabeçam uma lista de países que veem com certo receio o crescimento do número de fiéis muçulmanos. Além disso, associam o terrorismo internacional ao Islã.

\begin{abstract}
$\mathrm{Na}$ realidade, o ataque da al-Qaeda (al-Qa'ida, a Base) ao World Trade Center, em nova York, em 2001, foi apenas o auge de uma série de atentados cada vez mais audaciosos contra os interesses e símbolos norteamericanos. Porém, seu impacto foi muito maior que o dos anteriores, por atingir sua inviolabilidade territorial e pelo número espantoso de vítimas. Este "ato de guerra da ala mais extremista do islamismo contra a civilização ocidental em si” despertou uma fortíssima reação norteamericana na cena internacional (DEMANT, 2004, p. 184).
\end{abstract}

É comum entre os estadunidenses a chamada islamofobia, segundo Demant (2004), generalizando as práticas terroristas e cristalizando cada vez mais uma visão estereotipada e preconceituosa sobre o Islã.

Em países como o Brasil, o que chama a atenção é que, no passado, essa religião se concentrava basicamente entre os imigrantes sírios e libaneses e, agora, começa a se configurar como um grupo sem ascendência muçulmana.

Para Demant (2004), a América Latina é a parte menor e menos estudada do mundo muçulmano. Segundo o autor, a influência da Igreja Católica e a cultura latina são responsáveis por essa discreta presença. Depois do Brasil, está na Argentina a maior concentração de muçulmanos da América Latina. A origem desses grupos é a mesma da norte-americana; a maioria provém de imigrações no início do século XX.

No ano de 2001 foi um marco para a visibilidade do Islã no Brasil, fato que tornou esta religião mais uma opção no contexto religioso do país. Antes de 2001, eram pouquíssimas as conversões ao Islã; em Belo Horizonte, por exemplo, havia apenas dois convertidos brasileiros sem ascendência árabe. Depois de 2001, por 
motivos que serão apresentados adiante, o número de convertidos aumentou nas comunidades pesquisadas. Ao que tudo indica, porém, não foram os atentados às torres gêmeas, em Nova Iorque, na manhã de 11 de setembro de 2001, que provocaram maior visibilidade do Islã no Brasil. Talvez esses acontecimentos tenham suscitado, numa minoria, aspectos ideológicos em favor do Islã e uma reação antiamericana, mas não foram responsáveis pela opção religiosa de muitos muçulmanos nos brasileiros.

\subsection{Os acontecimentos de 2001 e a visibilidade do Islã na sociedade Brasileira}

Pinto (2010a) e Montenegro (2004) indicam que a telenovela "O Clone", de autoria de Glória Perez, exibida pela Rede Globo de Televisão, poucos dias após os atentados às torres Gêmeas em Nova Iorque, ocorrido em 11 de setembro de 2001, tenha sido um importante meio de desvinculação dos estereótipos produzidos pela mídia, principalmente após os atentados de 11 de setembro.

Os discursos estigmatizantes sobre o Islã no pós 11 de setembro não tiveram o monopólio da representação do Islã na esfera pública brasileira, uma vez que tinham de enfrentar a concorrência dos discursos de cunho positivo vinculados pela novela (PINTO, 2010a, p. 209).

A novela produziu, durante os seis meses em que esteve no ar, uma visão positiva do Islã para o público brasileiro, pois as telenovelas têm grande influência na cultura popular do país, criando modelos de vida e estilos. A telenovela tem, há várias décadas, feito parte do cotidiano do brasileiro e muitas são exportadas para outros países. A televisão brasileira tem sua marca na telenovela e, no caso de "O Clone”, confrontou a imagem do Islã e do muçulmano com a figura do terrorista, tão em voga após os atentados.

A telenovela "O Clone" estreou no horário nobre da TV brasileira, no dia $1^{0}$ de outubro de 2001, e teve grande audiência. O tema abordado foi a clonagem de seres humanos. O enredo se dava através do intercâmbio entre famílias brasileiras 
e marroquinas. Ora no Marrocos, ora no Brasil, apresentou-se a figura de muçulmanos alegres com fortes laços afetivos com o Brasil. A personagem principal, Jade, que vive entre a cultura islâmica e a brasileira, inspirou mulheres pela beleza e simpatia e, ao mesmo tempo, vivia a crise entre um amor brasileiro e um casamento resultante dos moldes tradicionais da cultura árabe. O tio desta personagem, Ali, interpretado por Stênio Garcia, mostrava, por um lado, a importância da preservação dos costumes e da tradição religiosa: "Desde o início, o público sabe que Jade vive a transição difícil de dois mundos, duas culturas” (MONTENEGRO, 2004, p. 249). No entanto, a afetividade transmitida pelos personagens, que descobrem poder viver sua crença religiosa num país de costumes tão diversificados como o Brasil, demonstrou um Islã fora daquele bloco monolítico do contexto geopolítico atual. A crise entre a tradição e modernidade ocidental revelou formas de coadunar crenças e costumes com a modernidade ocidentalizada, fazendo com que o tradicional fosse reinventado, sem perder de vista o amálgama que caracteriza a pertença religiosa.

Nas pesquisas realizadas, por Oliveira (2006) entre comunidades muçulmanas no Brasil pós 2001, todas apontam para o crescimento do número de convertidos posterior a esta dada; em Belo Horizonte, por exemplo, eles representam 40\% dos crentes e, em São Bernardo do Campo, o número vem crescendo consideravelmente, mas todos chegaram à comunidade depois de 2000, o que aconteceu também no Rio de Janeiro. Em algum momento nas entrevistas, crentes dessas três comunidades mencionaram a novela e como vislumbraram um Islã aqui no Brasil.

Entretanto, por mais importante que tenha sido a novela para a construção de ideário muçulmano, outros fatores também merecem destaque. Segundo Pinto (2010a), a visibilidade do Islã não pode ser devotada apenas às conversões pós 2001. Segundo esse estudioso da cultura árabe, as comunidades muçulmanas estabeleceram novos laços com a sociedade brasileira e o crescimento das 
conversões se deu nessas comunidades, que criaram canais de diálogo com os brasileiros e integraram os novos adeptos. O número de convertidos na comunidade muçulmana do Rio de Janeiro cresceu e atualmente corresponde a $80 \%$ do grupo. O autor classifica, ainda, quatro tipos de conversão ao Islã pelos brasileiros: conversão matrimonial, afetiva, intelectual e ideológica (PINTO, 2010a, p. 212).

As relações amistosas também foram ponto de destaque nas entrevistas. O carinho e o acolhimento dos brasileiros aproximaram as culturas e possibilitaram um diálogo que promoveu um conhecimento maior da religião.

Outro ponto observado por Pinto (2010a), e verificado nas visitas à comunidade do Rio, foi o fato de muitos membros estarem ligados a uma certa intelectualidade que promove destaque na comunidade e serve para se evitar o clichê de ser o muçulmano atrasado. Há, inclusive na comunidade do Rio, um comitê para a educação, no qual alguns membros se tornaram conhecidos por serem autores de diversas obras sobre o Islã e a ciência.

Porém, há ainda em número bem menor, aqueles que devotam sua decisão de optar pelo Islã por interesses ideológicos. Entre estes estão aqueles que defendem a ideia de que o Islã nunca foi uma religião racista e identificam a religião como uma resistência à opressão dos negros, isto pôde ser percebido tanto em Belo Horizonte como no Rio de Janeiro. Nessas comunidades, a causa negra é vista como uma motivação para a conversão, pois, de acordo com os relatos dos crentes, o Islã foi, na história, a única religião que não escravizou. Além disso, associam a figura do muçulmano às lutas norte-americanas de personagens com Malcom X e a resistência dos negros para sobreviver naquele país. Alguns, neste caso, citaram a revolta dos malês, mas sem muito destaque. 


\subsection{As comunidades muçulmanas no sudeste do Brasil}

No Brasil, as comunidades muçulmanas não são numerosas, porém, há comunidades muçulmanas organizadas em todas as regiões do país. Essas comunidades são hoje mistas e não podem mais serem consideradas grupos étnicos.

Mesmo diante de controvérsias que envolvem o Islã com o terrorismo, veiculadas cotidianamente pela mídia, essa religião vem demonstrando no Brasil, nos lugares em que se organiza e se relaciona com a sociedade mais ampla, um relacionamento aberto e dialogal, como participação em eventos sociais e ações de solidariedade junto com outras religiões.

Uma das características das comunidades muçulmanas do Brasil na atualidade é a figura do convertido, pessoa sem ascendência muçulmana que aderiu à religião. Como religião, o Islã quer ser universal, o que não significa que seja única, uma vez que cada comunidade possui a sua particularidade devido às diferenças étnicas e culturais que a constituíram.

Tais comunidades, embora independentes, mantêm laços interativos. Não formam um organismo hierárquico, como no caso da igreja católica - paróquias, diocese -, mas formam redes de solidariedades e sociabilidades. Essas comunidades religiosas foram aos poucos se inserindo de forma discreta na sociedade em que estão presentes. Entretanto, em alguns casos, como o de São Bernardo do Campo, sua inserção não tem sido tão tímida. Estão presentes em cerimônias cívicas, na rádio e TV, além de promoverem ações sociais e eventos de grande visibilidade social.

Nessas comunidades há esforços em desconstruir a imagem do Islã ligada ao fundamentalismo, à violência e ao terrorismo. As comunidades recebem nas mesquitas pessoas interessadas em conhecer o Islã e fornecem informações sobre o 
Islã e os muçulmanos.

Nas comunidades islâmicas do Brasil, a visão "distorcida" que os meios de comunicação têm sobre o Islã e os muçulmanos é combatida por meio de textos explicativos nos seus sites, nos quais é possível perceber certo desconforto com o que é divulgado pela imprensa.

Os muçulmanos não falam em proselitismo islâmico, mas ele fica claro no cotidiano das comunidades. Não é evidente como no caso evangélico, mas percebese a ocorrência dessa prática nas atividades promovidas pelas associações.

Adaptações das práticas religiosas são necessárias e têm sido feitas, como mudanças de horário e local das orações, sermões proferidos em português. Em São Bernardo do Campo usam-se equipamentos de tradução simultânea.

A relação entre os convertidos e os muçulmanos de origem árabe, por exemplo em Belo Horizonte, também é de certa tensão. Os convertidos tentam dissociar o Islã, enquanto religião, da cultura árabe. De qualquer forma, o Islã nas comunidades pesquisadas já não pode mais ser associado ao mundo árabe. Neste sentido, Pace (2005) lembra que as maiores concentrações estão na Ásia e na África negra, e não no mundo árabe. Porém, o elemento que remete à cultura árabe é a língua, pois o livro sagrado está escrito em língua árabe e a orações também são feitas em árabe. Em São Bernardo do Campo utiliza-se o meio de tradução simultânea, pois é uma comunidade com grande número de convertidos sem essa ascendência. Ao adentrarem na mesquita as pessoas que não dominam o idioma árabe recebem os aparelhos para acompanhar a prédica feita pelos sheiks nas sextas-feiras. Já no Rio de Janeiro e em Belo Horizonte, o sheik ou o imã faz um resumo da prédica em português.

Os costumes árabes são passados aos convertidos, principalmente em São Bernardo do Campo, onde questões culturais do mundo árabe e religião se confundem. 
Falar árabe em uma dessas comunidades é de certa forma um status simbólico. Os brasileiros convertidos sentem-se submetidos aos demais quando não dominam o idioma árabe. O idioma passa a ser um marco divisor nas sociedades e demarca um território simbólico, podendo às vezes servir como um elemento para estabelecer certo status dentro dos grupos.

Esta divisão entre os dois grupos está presente, embora de forma velada, nas comunidades em foco. Todavia, ela só vem à tona nos depoimentos ou é sentida através de um convívio com o cotidiano dessas comunidades.

A divulgação da religião vem sendo feita pelos próprios brasileiros convertidos, através de folhetos e livros produzidos pelo Centro de Divulgação do Islã para a América Latina - CDIAL, que é o órgão responsável pela produção e divulgação do Islã. $O$ órgão fornece subsídios para os divulgadores - material impresso sobre o Islã, livros, sites - e promove congressos. A comunidade do Rio de Janeiro promove um curso de introdução ao Islã e de língua árabe.

O CDIAL foi fundado em 1987. Fica localizado ao lado da Mesquita $A b u$ Baker Assedic, em São Bernardo do Campo - SP. Esse centro é responsável pela edição e produção do material de divulgação da religião, que é distribuído nas mesquitas e nos centros islâmicos do Brasil e da América Latina; ademais, organiza congressos e palestras e é responsável também pela publicação mensal do informativo "Alvorada”, que já tem mais de 90 números editados e o "Jornal Makka”. Também organiza congressos e palestras para muçulmanos de toda América Latina. Os encontros nacionais geralmente acontecem em São Bernardo do Campo e têm o objetivo de discutir a religião seus caminhos pelo mundo. 


\section{À guisa de conclusão}

A relação do Islã com o Brasil não é nova. Escravos malês e imigrantes, sírios e libaneses, fizeram esta história, embora em fases distintas. Foram os sírios e libaneses que construíram as bases do que são hoje as Sociedades Beneficentes Muçulmanas.

Chama a atenção o fato de que as comunidades muçulmanas no Brasil ainda estão em fase de transição: deixando a condição de comunidades étnicas para serem comunidades religiosas universais. Este aspecto deixa vislumbrar perspectivas para pesquisas futuras, uma vez que a dinâmica social de cada comunidade sofre alterações e mutações.

Os imigrantes construíram redes de sociabilidades que mantiveram canais abertos de diálogo com a sociedade brasileira, o que foi um diferencial importante que possibilitou a entrada nestas comunidades de pessoas sem ascendência árabe, que decidiram abraçar o Islã como religião. Esta abertura também favoreceu certa mudança na maneira de ver o Islã e os árabes, uma vez que estes foram alvo de fortes estereótipos.

A discreta relação destas comunidades com a sociedade mais ampla e sua inserção social não foram suficientes para desmistificar por completo todas as visões estigmatizantes sobre esta religião. A ideia de uma religião "de fora", "fundamentalista" e "violenta", ainda prevalece sobre as iniciativas dialogais e relacionais que estes grupos concretizam. Nos arredores das mesquitas, tem-se a visão de que o Islã não difere muito das demais religiões; é apenas mais uma.

A sociedade brasileira como um todo recebeu em pouco mais de uma década várias investidas que possibilitaram uma visão mais aberta em relação aos muçulmanos: a entrada de brasileiros sem ascendência árabe nas comunidades muçulmanas, o impacto da novela "O Clone", a iniciativa do diálogo interreligioso, membros das comunidades muçulmanas participando de eventos com outras 
religiões e os clubes sociais sírios e libaneses, abririndo-se para a sociedade. Estas iniciativas contrastam com os estereótipos e provocam, sem dúvida, a curiosidade popular de conhecer a religião de fora, demonstrando assim que os olhares estigmatizantes não são absolutos.

Ao que tudo indica, no interior destas comunidades coexistem duas realidades: os convertidos e os imigrantes. Estes preservam hábitos próprios de seus países de origem, além de traços da cultura árabe; aqueles vivem o dilema da identidade, pois reforçam a ideia de que abraçaram a religião, e não a cultura árabe. Embora estes dois grupos estejam empenhados na manutenção e organização das comunidades, a divulgação da religião ficou ao encargo dos convertidos.

A discussão apresentada neste artigo foi motivada pela necessidade de estudos que mostrem a inserção dessas comunidades muçulmanas na sociedade brasileira e deixa vislumbrar possibilidades de novas pesquisas que possam constatar se de fato as mudanças em curso, no interior destas comunidades, refletiram uma reconfiguração destes grupos capaz de romper com os estereótipos sobre esta religião e seus membros.

\section{REFERÊNCIAS}

AGUIAR, Andréia Nascimento de. Islamismo e Escravidão no Brasil (Um estudo sobre a presença de escravos muçulmanos na Bahia nos séculos XVIII e XIX). 1997. Dissertação (Mestrado). Universidade Federal de Juiz de Fora, PPCIR, Juiz de Fora.

BASTIDE, Roger. As religiões africanas no Brasil. v.1, São Paulo: Pioneira, 1971.

BAYAT, Asef. The use na abuse of "muslim societies". In: ISIM Newletter, n.13, Leiden, 2003.

CANCLINI, Néstor García. Culturas hibridas: estratégias para entrar e sair da modernidade. Sao Paulo: EDUSP, 1997. 
CASHMORE, Ernest. Dicionário de relações étnicas e raciais. São Paulo: Selo Negro, 2000.

DEMANT, Peter. O mundo muçulmano. São Paulo: contexto, 2004.

GUIBERNAU, Montserrat; REX, John (Ed.). The Ethinicity Reader: nationalism, multiculturalism and migration. 2. ed. Cambridge: Polity Press, 2010.

IBGE. Censo 2010. Disponível em: <www.ibge.gov.br/censo/censo 2010>. Acesso em: 12 dez. 2012.

JOMIER, Jacques. Islamismo. História e doutrina. $2^{\text {a }}$ ed. Petrópolis. Vozes, 1992.

LESSER, Jeffrey. A negociação da identidade nacional: imigrantes e minorias e a luta pela etnicidade Brasil. São Paulo: UNESP, 2001.

MONTENEGRO, Silvia. Telenovela et identités musulmanes au Brésil. Lusotopie, XI (1): 243-261, 2004. p, 249.

MONTENEGRO, Silvia. Dilemas Identitários do Islam no Brasil: a comunidade Muçulmana do Rio de Janeiro. 2000. Tese (Doutorado). Universidade Federal do Rio de Janeiro, IFCS, Rio de Janeiro.

MONTENEGRO, Sílvia. Identidades muçulmanas no Brasil: entre o arabismo e a islamização. Lusotopie. n. 2, 2002.

OLIVEIRA, Vitória Peres de. O islã no Brasil ou o islã do Brasil. Religião \& Sociedade, Rio de Janeiro, v.26. n.1. p. 83-114, 2006.

PACE, Enzo. Sociologia do Islã. Petrópolis: Vozes, 2005.

PINTO, Paulo Hilu da Rocha. Islã e civilização: uma abordagem antropológica. Aparecida: Ed. santuário, 2010a.

PINTO, Paulo Hilu da Rocha. Árabes no Rio de Janeiro: uma identidade plural. Rio de Janeiro: Cidade Viva; 2010b.

REIS, José João dos. Rebelião escrava no Brasil: a história do levante dos malês em 1835. São Pulo: Cia das Letras, 2003.

SANTOS, Delano J.S. Ummah e Identidade no Islã: um estudo do processo de construção identitária na Sociedade Beneficente Muçulmana do Rio de Janeiro. Dissertação (Mestrado em Ciência da Religião), PPCIR/UFJF, Juiz de Fora, 2010.

SAID, Edward. Orientalismo - O oriente como invenção do ocidente. São Paulo: Cia. das Letras, 1990.

SPOONLEY, P. Racism and ethnicity. $2^{\mathrm{a}}$ ed. Auckland: Oxford University Press, 1993. 
TRUZZI, Oswaldo. Sociabilidades e Valores: um olhar sobre a família árabe muçulmana em São Paulo. Dados - Revista de Ciências Sociais, v. 51, n. 1, p. 37-74. Rio de Janeiro, 2008.

VERGER, Pierre. Fluxo e Refluxo do tráfico de escravos entre o golfo do Benin e a Bahia de todos os santos: dos séculos XVII a XIX. $3^{\text {a }}$ ed. Trad. Tasso Gadzanis. São Paulo: Corrupio, 1987.

WANIEZ, Philippe; BRUSTLEIN, Violette. Os muçulmanos no Brasil: elementos para uma geografia social. ALCEU - v. I - n. 2. Jan-jul. 2001.

WALKER, C.J. O islão e o ocidente: Uma harmonia dissonante de civilizações. Lisboa: Edições 70, 2005.

WOHLRAB-SAHR, Monika. Simbolizando a distância: conversão ao islã na Alemanha e nos Estados Unidos. REVER - Revista de Estudos da Religião, São Paulo, n. 2, 2002. 